\title{
伝統医学と先端医学の融合に向けて
}

\author{
酒谷薰

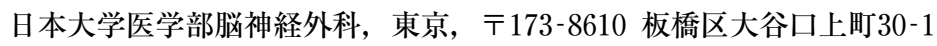

\section{Toward Integration of Traditional Medicine and Advanced Medicine}

\author{
Kaoru SAKATANI
}

Department of Neurological Surgery, Nihon University School of Medicine, 30-1 Ohyaguchi Kamimachi, Itabashi-ku, Tokyo 173-8610, Japan

\begin{abstract}
Functions of the human body in traditional Chinese medicine (TCM) are described in terms of Yin-Yang and the five elements. These ideas tend to be ignored in current research on TCM, since they are based on ancient Chinese philosophies which are considered incompatible with modern science. However, they may provide us with some new insights into human health and disease. In this paper, I will compare the characteristic view of human beings in TCM with that of western medicine.

The view of brain function is a distinctive characteristic of TCM. In TCM, the functions of the brain are dispersed to five zang organs, including heart and liver, and are maintained by comprehensive functional interactions among the five zang organs. Therefore, in contrast to modern western medicine, brain diseases are regarded as systematic diseases in TCM, and their treatments are aimed to normalize not only the activity of the organs, but also the balance of functional interaction. Another characteristic of TCM is that much importance is attached to the interaction between human beings and the environment. This is in contrast to modern western medicine, which tends to regards human beings as independent of their environment. These features of TCM derive from its theoretical basis in Yin-Yang and the five elements. The whole idea of Yin-Yang theory is expressed by the Tai-Chi symbol (figure). The black and white areas in Tai-Chi symbol means that the whole world, including human beings, consists by two opposing components, namely, Yin (black area) and Yang (white area). Importantly, each component exists within the other component; the white and black areas contain small back and white circles, respectively. The world is considered to be infinitely divided into Yin and Yang, and each part has a similar structure to the Tai-Chi symbol. The world, including the human body, in Yin-Yang theory, therefore, has fractal geometry. In addition, interestingly, the functional interaction between the five zang organs in TCM resembles a biological model based on chaos theory.

In conclusion, TCM had co-opted the basic idea of a complex system for the diagnosis and treatment of human diseases thousands years ago. Research into TCM should not only evaluate the effects of herbal medicine or acupuncture, but should take into consideration the view of human beings in TCM. Such studies may help us to understand disease in terms of the relationship between humans and the environment.
\end{abstract}

Key words : Traditional Chinese Medicine, Yin-Yang and the five elements theories, fractal, chaos, complex system, near infrared spectroscopy, frontal lobe, autonomic nervous system, hormonal system, aroma therapy

\section{要旨}

中国伝統医学（以下, 中医学）では，陰陽五行学説を基礎として人体機能を考えている。陰陽五行学説は古代中 国の自然哲学であり，難解で不可解なものとして日本漢方では重視されてこなかった。しかし，陰陽五行学説を現 代科学の視点から見直してみると, 両者には共通している点が少なくない。本講演では, 陰陽五行学説の考え方を 現代科学の観点から読み解き，これを基にして中医学の人体機能や病態に対する考え方について解説する。

1. 陰陽五行学説亡複雑系

陰陽五行学説は陰陽学説亡五行学説から成り立っている。ます陰陽学説であるが, 太極図の中にその意味するこ とが全て示されている。太極図で注目すべき点は，白（陽）と黒（陰）の中に反対要素である極化点が存在するこ とである。これにより人間を含めた世界というものは無限に陰陽に分割され，その全ての部分が太極図と同じ構造 を持つことになる。すなわち, 部分が全体を示すというフラクタルな世界観を示している。中医学では, 舌や耳等 
の身体の一部分に全身状態が反映されていると考えるが，もし人体がフラクタルな構造を持つと仮定するとこの考 え方も理解できる。一方の五行学説は, 中医学における臟器機能の基礎となっている。五行学説に従って藏腑（五 臟）は木·火·土·金·水の 5 種類に分類され，各臟腑の間には相生 (=positive feedforward) と相克 (=negative feedforward）という力学的関係が存在し，その相互作用により全体の機能バランスが維持されていると考え る。興味深しことに，この考え方はカオス理論に基づいた生体モデルに酷似している。このように陰陽五行学説の 考え方は, 現代科学の複雑系理論に通じる点が少なくない。

2. 中医学における人体機能と病態

中医学における臟器の特徵は, 脳が臟腑（五臓六腑）に含まれていない点である。すなわち中医学では, 脳のさ まざまな機能を五行学説に従し五臟六腑や関連する器官に分散させているのである。このため脳疾患は単一臟器の 障害ではなく, 上述の臟器間の機能バランスの障害による全身性疾患と考えられている。もう一つの特徵は, 陰陽 学説のフラクタルな世界観によりヒトと環境を一体として捉えている点である。つまり西洋医学では, ヒトは皮膚 などのさまざまな「膜」により外界より分離した環境を保つことにより生命活動を維持していると考えるが，中医 学では, ヒトは環境と一体化して存在し, ヒトの機能は環境から強い影響を受けると考えられている。

3.まとめ

陰陽五行学説に基づいた中医学の人体機能に対する考え方は, われわれの西洋医学と異なるが, 非科学的なもの ではなく現代科学にも通じるユニークなものである。中医学と現代科学を融合させた新しい医学の構築に向けて, 伝統医学研究は，その治療効果に加えて生命観に関する理論的研究も重要と思われる。

キーワード : 中医学, 陰陽五行, フラクタル, カオス, 複雑系, 近赤外分光法, 前頭葉, 自律神経, 木ルモン系, 香療法

佐藤 ただいまから，酒谷薰教授による教育講演 を拝聴させていただきたいと思います。私は十河会 頭より座長を命ぜられました，愛知学院大学の佐藤 でございます。酒谷教授のご略歴等につきましては, ここに書かれておりますので私から申し上げること もないのですが, 現職は日本大学医学部脳神経外科 教授ということです。一つだけ，医学博士と工学博 士と両方持っていらっしゃるということで, 先ほど 少しお伺いしましたところ, 社会人入学で北海道大 学の大学院にご入学なさって工学博士を取られたと いうことです。こういう大変素晴らしいご経歴を 持っていらっしゃいます酒谷薰教授に,「伝統医学 と先端医学の融合に向けて」ということで教育講演 を拝聴させていただきたいと思います。

先生方にはいろいろ持間の予定が拉ありと存じ ますが，ぜひ終わりまで聞いていただけるとありが たいと思います。それでは酒谷先生，よろしくお願 いします。

酒谷 佐藤先生，ご丁寧な紹介をありがとうござ います。最初に，このような機会を与えてください ました十河会頭に心より感謝を申し上げたいと思い ます。

私は，先ほどご紹介がありましたが，脳神経外科 という東洋医学とは最も対極にある侵襲的な治療法 を行う医師であります。また，人間を機械として扱
いがちな工学というものも専門としております。な ぜ私のようなものがこういうところで括話しさせて いたただけるのか，その背景をまずご紹介したいと 思います。

\section{中日友好病院での中医学との出会い}

私は1995年から 6 年余り, 北京市の中日友好病院 に勤務しておりました。この病院は, 日本の ODA により1984年に設立された病院ですが，中西結合を 目的とした病院ということで, 1400床の内の400床 が中医学の専門病棟でした。実はこの病院に赴任す るまで, 先見の明がないと申しますか, 私は中医学 あるいは東洋医学といった伝統医学にほとんど知識 も興味もなかったのです。この病院にも JICAの専 門家として派遣され, 脳神経外科や神経科学の技術 指導が目的だったのです。ところが，院内の中医と 呼ばれる漢方医と一緒に研究したり, 神経疾患の患 者さんを診たりする機会にめぐり合ったのです。そ して, 彼らから直接中医学の手ほどきを受け，これ は大変面白い, 素晴らしい医学であるということに 初めて気がつき, それ以来, 中医学の魅力に取りつ かれております。

私は, 中日友好病院に赴任した時, 近赤外分光器 という新しい脳循環測定器を日本から持っていきま した。先ほどの小柴先生のご講演の中で浜松ホトニ クスという名前が出ましたが，この機器も浜松ホト 


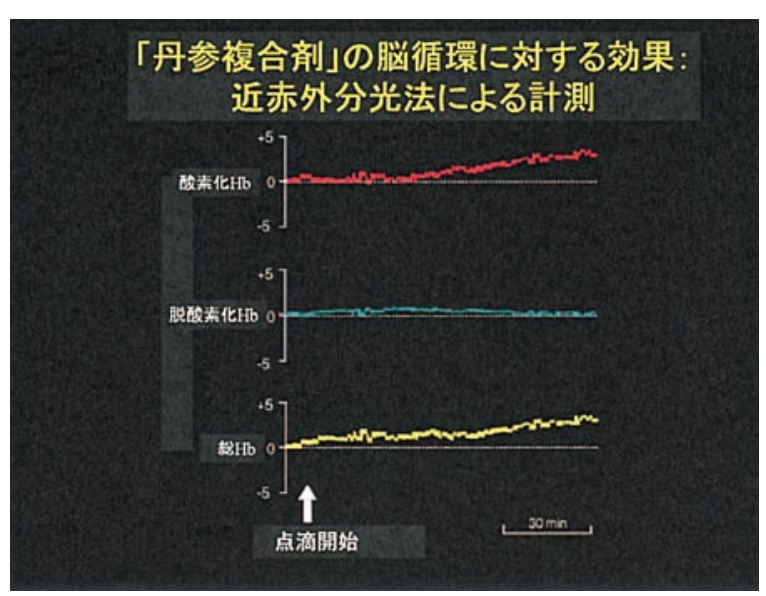

図 1

ニクスが開発したもので, 非常に微細な光を検出す る光電子倍増管を使用し, 頭皮の上に光センサーを 置くことにより脳の血液循環を測定できるのです。 この測定器を使用して, 院内の先生たちと脳科学に 関する臨床研究を始めたわけです。最初は脳外科医 や小児科医などの西洋医の先生達と研究していまし たが, ある時, 中医の先生が漢方薬の効果を調べた いということで, 研究室を訪ねて来られました。私 は, どういう漢方薬かと聞いてみたところ, 復方丹 参（ふくほうたんじん）という点滴剤だったのです。 漢方薬というのはエキス剤とか, 煎じ薬ぐらいに 思っていましたので, 中国には漢方薬の点滴剤があ るのかと大変驚いた次第です。

早速, 近赤外分光器で調べてみましたが, スライ ドがその結果です（図１）。一番上の赤い線，これ が酸素の付いた酸素化へモグロビン，2番目のブ ルーの線が酸素の付いていない脱酸素化へモグロビ ン, 3 番目のトータル・ヘモグロビンというのは血 液量を表しています。丹参の点滴剤を始めますと, 赤い線が徐々に上がって拈りますが，これは脳血流 が増えているということを示しているわけです。こ の時まで臨床経験でしか分からなかった中医薬の効 果が, こういう先端的な測定器で客観的に評価でき たことに中医の先生方は大変喜びまして, それ以来 いろいろな中医学の共同研究をするようになりまし た。

前置きはこれぐらいにしておきまして，これから 本題に入ります。講演内容は大きく三つに分けるこ とができます。まず, 中医学の理論的基礎となって いる除陽五行学説の意味するところは何か, フラク タルあるいはカオス理論などと呼ばれる複雑系の視
点から解説したいと思います。次に, 中医学におけ る脳と心とはどういうものか括話いたします。中医 学の五臟六腑などの臓器の中には脳が含まれており ませんが，中医がどのように脳の機能や疾患を理解 しているのか解説し, 西洋医学と中医学の脳と心の 考え方の違いを考察していきます。そして最後に, 脳科学の視点から中医学の治療効果を検討した最近 の研究結果をご紹介します。この研究では, 中医学 の香療法, 最近はアロマテラピーとして巷で流行っ ていますが，香りを使ってストレスを緩和する治療 のメカニズムを，先ほどご紹介した近赤外分光法を 用いて検討しました。この部分は最近得られたデー タですので抄録には入っておりませんが, 最後にご 紹介させていただきます。

\section{陰陽学説とフラクタル}

さて, 中医学には, 生薬, 鍼炎, 按摩, 気功, 薬 膳と，いろいろな治療手段がありますが，それはす ベて同じ弁証論治という診断治療の原則に基づいて おります。日本の場合, われわれ医師が行なう漢方 治療と鍼尒師の行う鍼尒との間には大きなギャップ がありますが, 中国では一人の患者さんを同じ弁証 論治に基づいて，あるときは生薬，あるときは鍼炎 で治療することが良くあります。ちょうど西洋医学 の内科医と外科医が一人の患者さんを治療するよう なものです。

その弁証論治の根底にあるのが古代中国の自然哲 学である陰陽五行学説です。現代の中医学でも陰陽 五行学説を大変重視していますが, 日本の漢方は, その歴史の中で陰陽五行学説を排除し, シンプルな 臨床的な医学に変貌しました。このため日本では, 除陽五行学説は古くさい考え方で, 臨床的にもあま り意味がないということで顧みられなかったわけで すが，実は，私はそこのところが面白いと思ったの です。

では，一体，陰陽五行学説のどこが面白いと感じ たのか，㧍話したいと思います。陰陽五行学説は, ご承知のように陰陽学説と五行学説の二つに因数分 解されます。まず，陰陽学説ですが，太極図の中に 除陽学説のすべての意味が込められております。白 の部分が陽 (火や昼など熱いもの), 黒の部分が陰 （水や夜, 冷たいもの）で, こういう対立関係のあ るもので世の中が構成されていることを示していま す。ここが一つの出発点であるわけです。 


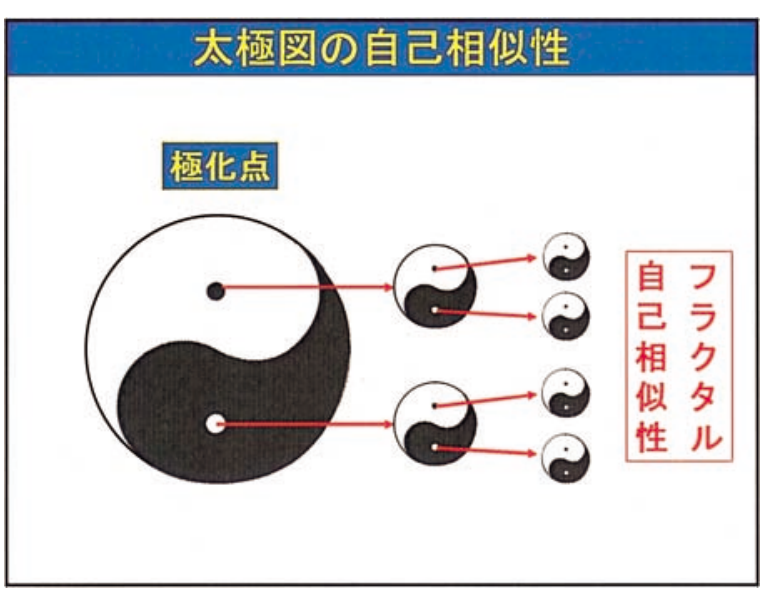

図 2

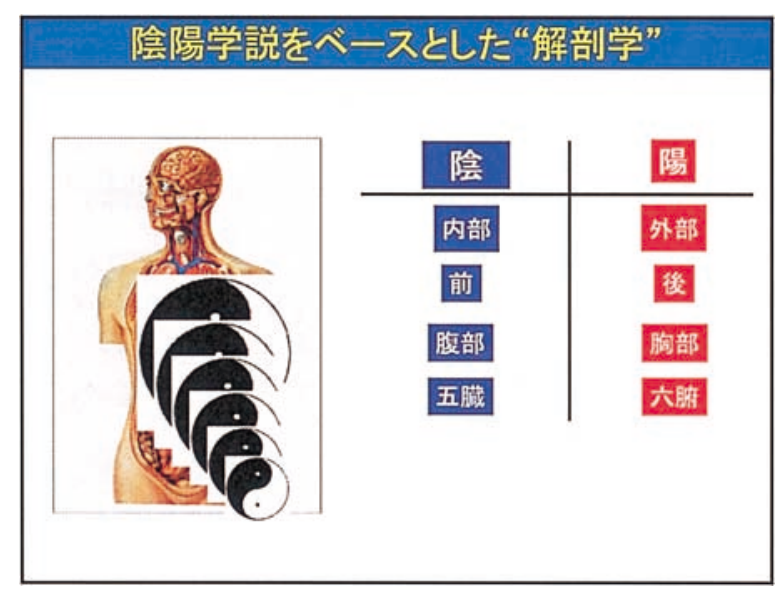

图 4

私が太極図で非常に重要で，そして面白いと思っ たのは，この極化点と呼ばれる陽の中にある陰，陰 の中にある陽であります。これは何を表しているか といいますと，陰陽というのは相対的なもので，陰 の中にも陽があり，陽の中にも陰が存在するという ことであります。つまり，この極化点を拡大すると， 同じように太極図が出てくる, さらにその中の極化 点を拡大すると, 同じょうに太極図が出てくるとい うことであります（図２）。つまり，宇宙は無限に 陰陽に分けられ，どの部分も同じ構造をしていると いうことを意味しているのです。これは数学的には 自己相似性あるいはフラクタルと言われるものであ ります。

実際，この自己相似性を持った形というのは自然 界にもたくさんあります。例えば，これは冬のガラ ス空にできた氷の結晶ですが，この部分を拡大する と全体と同じ形になります。つまり部分と全体が同 じ構造をしているフラクタル図形なのです。ただ， 自然界の中のフラクタルというのは, 完全に部分と

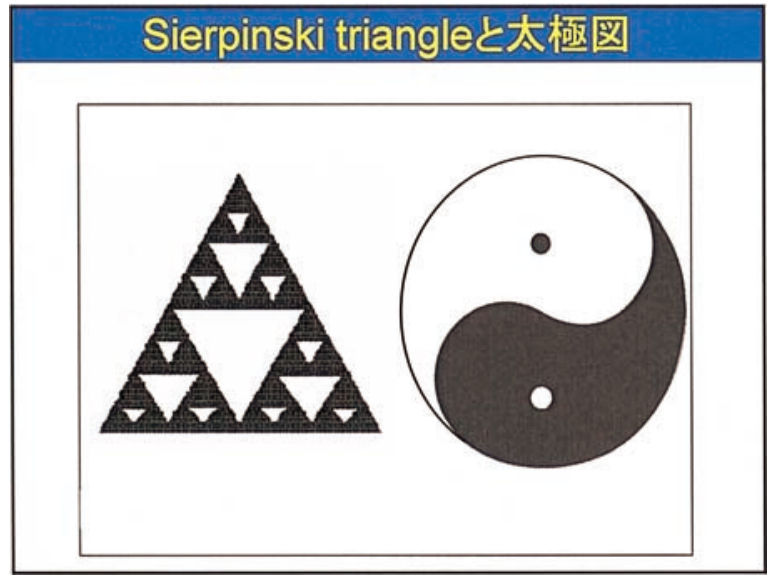

図 3

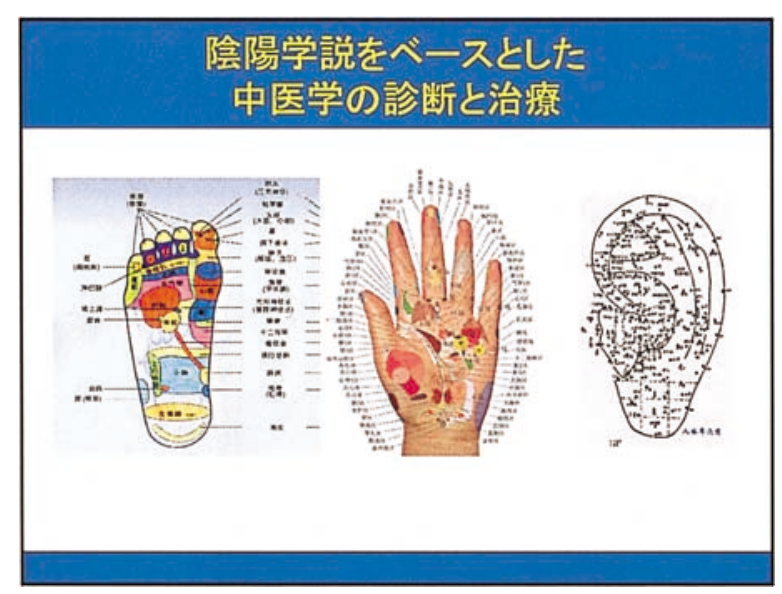

图 5

全体が同じ構造をしているわけではありません。あ くまで似ているという程度であります。ところが， コンピューターを用いると, 完ぺきなフラクタル図 形を作ることができます。例えば，シルピンスキー ・トライアングルと呼ばれるフラクタル図形です

(図 3 左)。最初に，正三角形がありますが，この 中点を結んで中をくり抜く。それぞれの黒いところ をまたくり抜いていくと，どんどん正三角形の穴が 増えていくわけですが，この部分を拡大すると全体 と同じ形になるということで，完ぺきなフラクタル 図形であります。

この図を見て思いましたのは，もしこのシルピン スキー・トライアングルの黒のところを陰，白のと ころを陽と考えれば，太極図とシルピンスキー・卜 ライアングルというのは同じこと，すなわちフラク タルな世界観を意味しているということであります。 私は, 古代中国の哲学者と現代の数学者が同じこと を考えていたことに大変驚いたのです。 


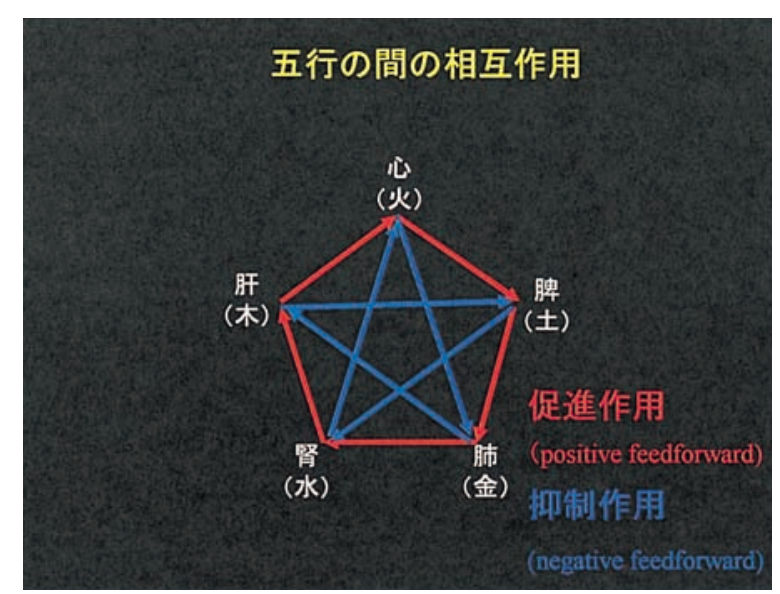

図 6

\section{陰陽学説による中医学の解剖学と診断治療}

次に，陰陽学説によるフラクタルな世界観が，ど のように実際の医療に応用されているか見ていきま す。まず，人間を含めた自然に対する考え方です。 われわれ現代人にとっては, 宇宙, 地球, 自然, 人 間，これらは全て異なった構造をしていると考える わけですが，陰陽学説に従いますと，これらがすべ て同じ構造，太極図と同じ構造をした存在になるの です。この考え方は，後ほど詳しく述べますが，人 間と自然界の関係を考える上で重要な役割を果たし ています。そして, この考え方は, 解剖学にも応用 されているのです。左側は西洋医学の解剖図譜であ りますが, 中医学の陰陽学説をベースとした解剖学 では, 例えば体の内部は陰, 外部は陽, 前側は陰, 後側は陽, 腹部は陰, 胸部は陽, さらに五藏は陰, 六腑は陽というように，どんどん身体を陰陽に分け ていくわけです（図４）。これを続けていきますと， 結局，人間の身体はどこを取っても太極図と同じ構 造をしている。つまり，身体のどの部分も全体と同 じ構造をしたフラクタルな構造になり, われわれ西 洋医と全く異なった解剖学が生まれるわけです。

(注：図4 はアニメーションを使用しているため, 左の西洋医学解剖図譜に太極図が重なっている)

さらに, このフラクタルな解剖は, 中医学の治療 にも応用されているのです。例えば, 近頃, 流行っ ている足亭マッサージです。これはもともと中医学 の治療法なのですが, この治療法では, 足の裏の各 部分に例えば肝であるとか, 心であるとか色々な臓 腑の情報が入っていると考えるわけです。また，耳 にも銊を打って治療する耳針法というものがありま すが，それもまた耳という部分の中に全身の情報が
入っていると考えるのです。

私は最初にこの図（図5）を見たとき，それぞれ の臓器と経絡か何かで結びついているのかなと思っ たのですが，どうもそうではない。全体の臓腑の情 報が足の裏や耳に表れていると考えるのです。足裏 マッサージはリフレクソロジーと呼ばれることもあ りますが，あれは反射法という言葉を英語に直した ものであります。しかし，反射というのはいわゆる 腱反射などの反射“リフレックス”ではなく“リフ レクション”，部分の中に全体の情報が “反映”し ているという意味だと思います。われわれ西洋医が こういう図を見ても理解に苦しみますが，もし人間 の身体がフラクタルな構造をしているということで あれば，それなりに納得できるわけです。

\section{五行学説とカオス生体モデル}

もう一つの五行学説ですが, 陰陽学説よりも取っ 付き難い面があるように思います。例えば, 中医学 の教科書に書かれている五行学説の解説を読みます と, 世界は木 · 火 $\cdot$ 土·金·水の 5 種類の基本物質 で構成されていると書いてあります。この時点でわ れわれ現代科学を知っている者にとっては拒否反応 が起きるわけです。私は同僚の中医に「本当にその ように信じているのですか?」と聞いてみたところ, 「まさか，そんなこと信じていませんよ」と答え， スライドに示した図（図6) を描きながら「五行学 説では, それぞれの要素が扔互いに他の要素と影響 を及ぼし合ってバランスを保っているこのことが 一番大事なのですよ」と教えてくれたのです。

この図 6 は皆さんよくご存じの五行の間に働く相 互作用です。木・火・土・金・水は，それぞれ肝· 心・脾・肺・腎に相当し, 赤で示す「相生」, 青で 示す「相克」という作用が働くわけですが，私は中 医学を勉強し始めた頃, なかなかその意味が理解で きませんでした。中医学の教科書を読みますと,「相 生とは, 金は水を生じ, 水は木を生じ, 火は土を生 じ，土は金を生ずるが，すなわち生成の道にして循 環して極まりなし。相克とは，その過ぎたるを制し て, 平らに帰せしめることなり」と解説しているの です。いわゆる文系・理系と分けると私は理系の人 間なのですが，理系の人間にとって，こういう表現 は非常に抵抗感があるといいますか, これだけで腰 を引いてしまうのです。しかし, 相生をポジティブ ・フィードフォワード，相克をネガティブ・フィー 


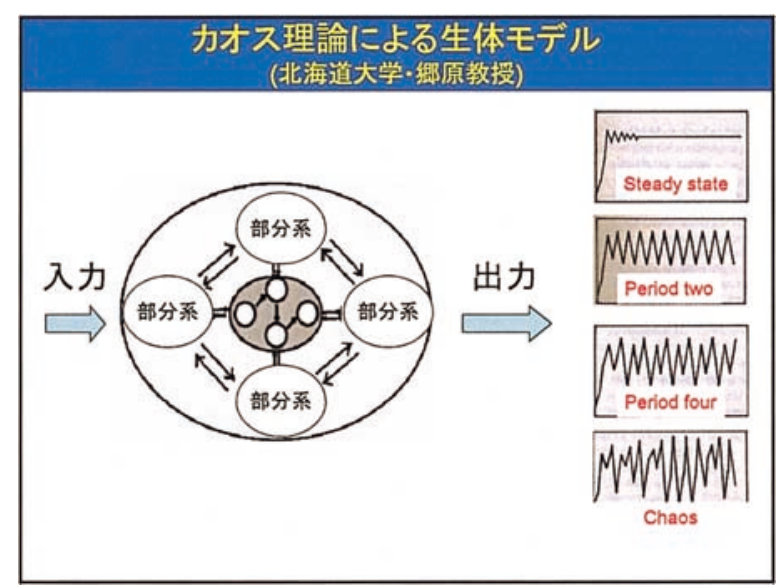

図 7

ドフォワードと考えると，この五行の図が，俄然， 物理的な生物モデルに見えてきたのです。

ちょうどそのことに気がついた頃に, 北京で開催 された生物物理の国際学会に出席しておりましたと ころ，たまたまカオス理論を基にした生体モデルと いうのを考案されている北海道大学の郷原先生にお 会いしたのです。カオス理論というのは，天候のよ うな予測不可能な複雑な現象の中にも簡単なルール, 方程式で記述できるものがある。つまり，確率論的 なものではない，決定論的だけれども予測不可能な ものがあるというのがカオス理論であります。少し 前に，一般書でもよく取り上げられましたのでご存 知の方も多いと思います。

さて, 郷原先生に例の五行の図を扮見せして,「こ れは何かの生物モデルに見えませんか? 」と尋ねた ところ，先生は「私が作っているカオス理論をべー スにした生物モデルによく似ています」と扔っ しゃって，論文を送ってくれました。その論文の中 の図がこれです (図7)。モデルの中に幾つか部分 系というのがありますが，外から入ってきた入力信 号を部分系がお互いに信号をやり取りしながら処理 して最終的に出力される。この部分系というのは簡 単な決定論的な方程式で表されますが，生体システ ムから出てくる信号は, 部分系の方程式のパラメー ターを少し変えるだけで，Steady state，Period two, Period four などの周期的変化に加えて，最終的には カオスという予測不可能な信号が出てくるのです。

私がこれを見た時に，中医学の五行の人体モデル にすごく似ているなと思いました。図の左はカオス 生体モデル，右は五行学説による人体機能を示して います（図８）。肝・心・脾・肺・腎をカオス生体

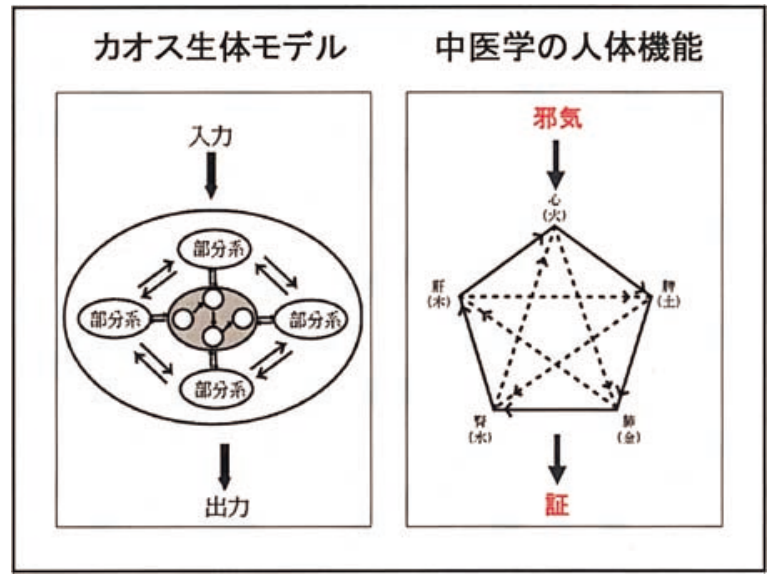

図 8

モデルの部分系として考えれば，外から入った外邪， 邪気の信号が，五臓の間で相生・相克の関係でやり 取りされて出力として証が出てくると考えることが できます。つまり，中医学の臟器機能に対する考え 方と現代のカオス生体モデルは本質的には同一のも のと言えるのです。

\section{中医学と西洋医学の本質的な違いは何か ?}

次に，中医学と西洋医学は本質的に何が異なるの か，これから考察していきます。私は，その差異の 一つは解剖に対する考え方のように思います。スラ イドの左側はレオナルド・ダ・ヴィンチの 15 世紀に 描かれた解剖の絵です。現代の解剖学の教科書にし てもおかしくないぐらい細かく観察され，描写され ています。一方，右側はそれから200年以上後の日 本人の描いた解剖図譜なのですが，非常に観察が甘 いといいますか，これが何となく肝臓だなとか，こ れは肺だなというのは分かりますが，このレオナル ド・ダ・ヴィンチが描いた精密な解剖図譜と比較す ると随分と劣っているように見えます。私は，この 違いは西洋人の解剖に対する執念といいますか，対 象を要素として分析していく伝統を有する西洋の文 化からきているのではないかと考えています。

では，東洋の医学は西洋に比べて劣っているのか というと，私はそうではないと思います。西洋医学 というのは解剖学をべースにした医学です。外科は もちろんですが，内科の先生も解剖を基にして病態 を考えます。患者さんに説明をするときにも，例え ば心臓が悪いときには心臓の絵を描きながら説明す るわけです。ところが，中医が患者さんの病態を私 に説明してくれる時に，彼らは解剖の絵を描かない のです。まるでコンピュータープログラムのフロー 


\section{古代の中医は“脳”を知らなかったのか？}

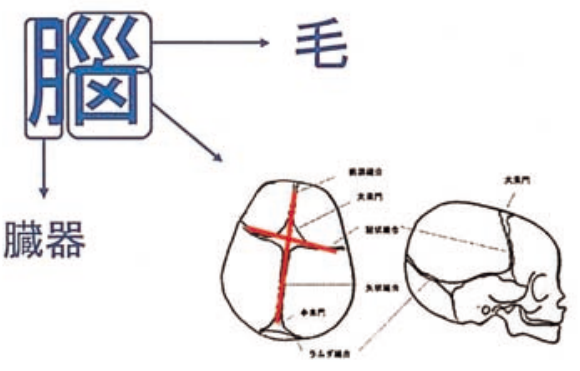

(白川静著「常用字解」平凡出版社より)

図 9

チャートのように, 腎の陰がどうのとか, そういう ものを図でどんどん細かく示してくれたのです。こ のことは, 中医が解剖をあまり重視していないこと を示す一つの例だと思います。では，どのように考 えたかというと, 彼らは複雑系の数学モデルのよう に人体の機能をとらえたのではないかと思うわけで す。

中医学に興味のない西洋医は, 心は心蔵の機能と 違うし, 肝と肝臓の機能もどうも違う, われわれの 知っている解剖と合わない。あの辺がどうも信用で きないという言い方をよくしますが，そうではなく て, 中医学は解剖よりも機能を重視するのです。つ まり肝とか心という中医学の臟腑は, 言わば架空の 臓器であって, その臓腑の機能というのは, 例えば 生薬の効果から帰納的に推定したものではないか。 それを数学的な生体モデルように組み立てながら人 体機能を理解していったのだと私は想像しています。 ですから, 何も解剖と一致しないからといって西洋 医学より劣っている医学ではなく, むしろ西洋医学 が未だ取り入れていない斬新な数学モデルをべース にした医学ではないかとも考えるわけです。

\section{中医学における脳と心}

次に, 中医学における脳と心についてお話しした いと思います。もちろん西洋医学では脳というのは 心を生み出し, そして身体をコントロールする, 非 常に重要な臟器でありますが, 中医学ではどうで しょうか。ご承知のように中医学の臟器というのは 五臓六腑, それから五体があります。五臓 (心・肝 - 脾 - 肺 - 腎), 六腑 (胆囊 - 胃 - 小腸 - 大腸 - 膀 胱・三焦), それから五体とは脈 (血管) - 筋 (腱 や䩲帯）・筋肉・皮・骨ですが，この中に脳という
臓器は全く入っていないのです。現代の中医は，こ の脳のない五臓六腑, 五体で脳疾患, 例えば，脳卒 中の患者さんの病態を理解し, 治療しているわけで すが，どのように考えて診断治療を行なっているの か，私は脳外科医として非常に興味がありました。

まず，脳という臟器は一体いつごろ中国で認識さ れたのでしょうか。白川先生の『常用字解』という 語源辞典をもとに, 脳の語源を調べてみました（図 9)。そうしますと，この「腦」という字の上の 3 本の「く」の字（「《」）というのは毛を表している ということです。この口の中の「メ」というのは, 赤ちゃんの頭蓋骨の縫合線を表しているということ です。赤ちゃんの縫合線, 冠状線と矢状縫合線はま だ融合しておりませんので，このように十字に見え る。この周りの格好が口であるということで，これ は頭蓋骨を上から見たところを表しているわけです。 その上に毛がある。そしてこの「月」というのは蔵 器を表している。つまり, 脳という漢字は, 脳が頭 蓋骨の中にある臓器であるということを示しており, 古代の中国では脳が認識されていたことが分かりま す。

では, 古代の中国人は, 脳の機能を知っていたの かという疑問が出てきます。私は「悩」という字に 注目しました。「悩」の右側のところは「脳」と同 じ構造をしています。ですからこれれは脳を表して いる。偏は心であります。ですから, 脳が悩みを生 み出すことは知っていたということまで推定できる わけです。おそらく悩むと頭が痛い, あるいは頭を 抱えるとか, そういうことから脳は悩みを生み出す 臓器なのだろう，そういうところまでは古代の中国 でも理解されていたのではないかと, この漢字から 想像されるわけです。

事実, 古代の中医は脳を認識していたのです。『黄 帝内経』の中に, 奇恒の腑という臓器の分類があり ますが，脳・髄（骨髄）・骨・脈（血管）・胆（胆 囊）・女子胞（子宮）がそれに当たり, 脳が入って いたのです。しかし, 脳の機能というのは非常に複 雑であります。彼らは脳の詳細な機能を知ることが できなかったため, 次第に脳という臓器を中医学の 臓腑から除外したのだと思います。ただ，西洋医も そんな大昔に脳の機能を知っていたわけではなく, ペンフィールドという脳外科医が脳機能の地図を 作ったのが20世紀前半ですので，われわれ西洋医も 


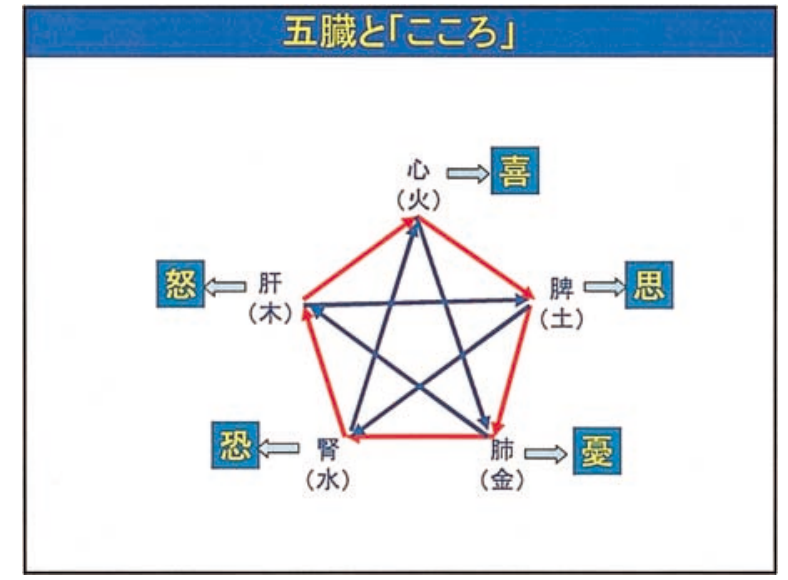

図10

脳機能を理解し始めたのはたかだか100年であり， 現代も脳の機能の多くのところが分からないという のが現状であります。

では，古代の中医は脳の機能をどのように理解し ていたのか見ていきましょう。皆さんは東洋医学の 専門家ですので，釈迦に説法で申し訳ないのですが， 私が中医から教えてもらいながら中医学というもの を理解していった過程をお話したいと思います。

脳の大切な機能の一つに感情があります。前頭葉 などが感情を生み出す重要な領域であることが分 かってきましたが，中医学では，脳のない臓腑でど のようにして感情が生まれると考えるのでしょうか。 それは，皆さんがよくご存じの五臓と感情の関係で あります（図10)。つまり，心は喜ぶ，脾は思う， 肺は憂う, 腎は恐れる, 肝は怒る。それぞれの臓腑 はこのような感情を生み出し, また逆にこういう感 情が過ぎるとそれぞれの臓腑の機能が冒されるとい う発想です。

ここで大切な点は, 中医学と西洋医学の脳と身体 に対する考え方の違いです。西洋医学では, 脳は身 体の機能を支配する臓器と考えますが，中医学の場 合は，先ほど述べましたように，脳が身体に分散し ている，脳の機能が五蔵を中心に身体に分散してい ると考えるのですね（図11）。そして私は，このこ とが心身一如ということだと理解しました。つまり， 心身一如の意味するところは, 脳の機能が全身に散 らばっているという中医学の考え方に基づいている のだ，と私なりに理解したわけです。

\section{中医学におけるヒトと環境の関係}

さて, もう一つ, 西洋医学と中医学の違いで大切 なところは，人間と周囲環境との関係に対する考え
西洋医学と中医学における脸とからだ

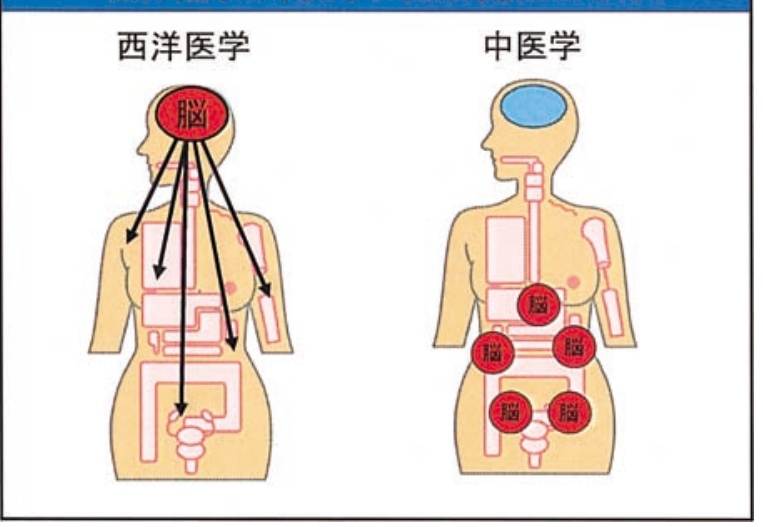

図11

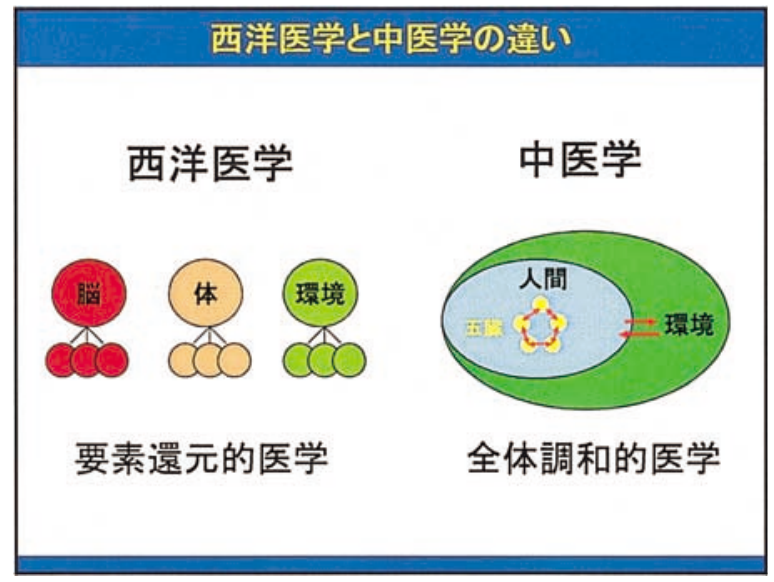

図12

方だと思います。西洋医学では対象を要素に還元し て理解していきます。例えば，人間の身体もどんど ん部分に分け，脳もさらに部分に分ける。さらに人 間を環境から切り離し，人間というのは環境から切 り離された存在だと考えます。西洋医学では, 内部 環境を維持する細胞膜の誕生が生命現象を生み出す 最初のきっかけと考えるわけですから, 当然かもし れません。

一方, 中医学の場合は，人間と環境の間の相互作 用を非常に重視しています。つまり, 中医学では細 胞膜のような解剖学的なことはあまり重視しません ので，人間と環境は，言わばッーツーの関係になっ ている。そして，人間と環境が互いに相互作用を及 ぼし合いながら調和を保って存在していると考え， 中医学では，このことを天人相応と言います。西洋 医学との違いを図で示すとこういうことだと思いま す(図12)。西洋医学を要素還元的な医学, 中医学 は全体調和的な医学という呼び方ができるかもしれ ません。このように西洋医学と中医学とでは, 人間 


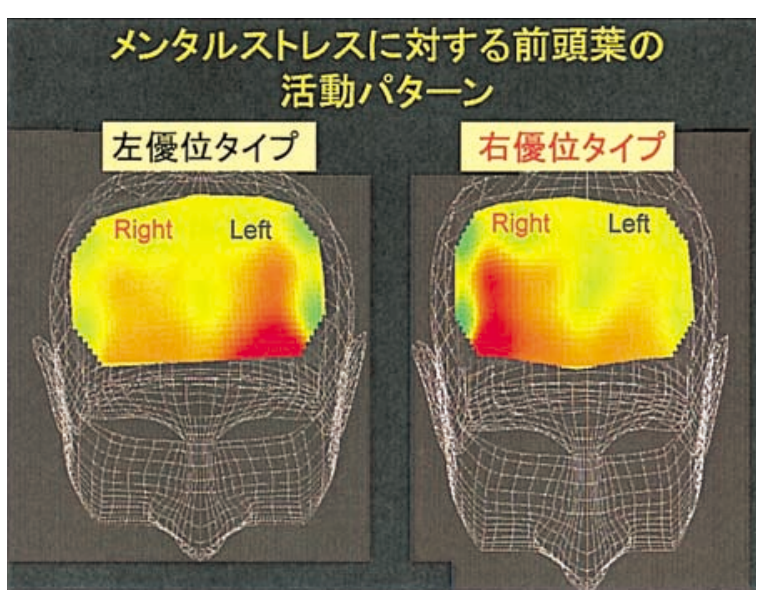

図13

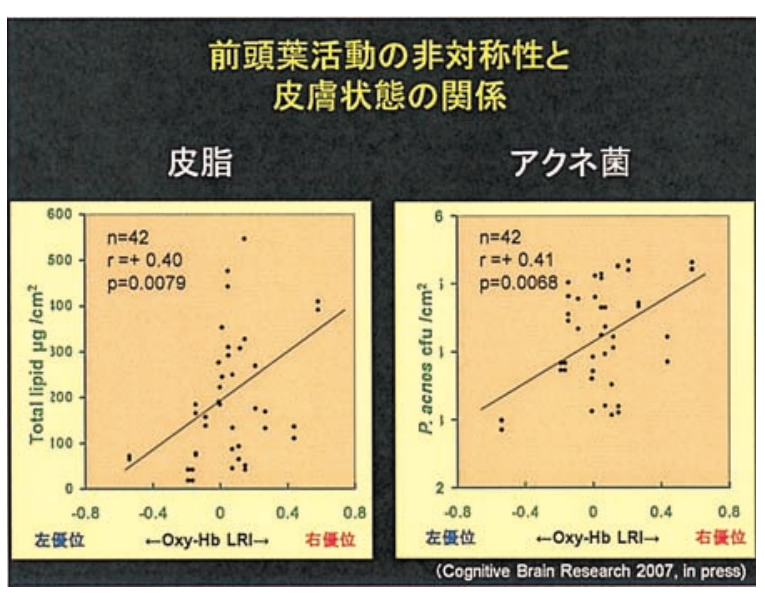

図15

に対する見方，パラダイムが全く異なるわけです。

次に，これらのパラダイムをもとに，脳の治療法 が西洋医学と中医学でどのように異なるのか考えた いと思います。脳を活性化する方法の違いと言い換 えても良いでしょう。まず西洋医学ですが，脳とい う臟器を身体から分離して考えて治療するのが原則 です。例えば，抗うつ成あるいは精神安定剤，そう いうものは脳をターゲットとして余計なところに行 かせない，できるだけピンポイントに薬物をデリバ リーする, それが西洋医学の脳に対する治療法であ ります。最近,「大人の計算ドリル」などの脳トレ が流行っていますが，これも脳だけを鍛えようとす る意味で要素還元的な脳の活性化法と言えるかもし れません。

一方の中医学はどうかといいますと, 太極拳ある いは気功など身体を動かすことで脳を活性化する。 また環境を調節することで身体を活性化し，さらに それを介して脳を活性化する。例えば，いろいろな 香りをかいで治療する香療法というのは，環境，身

\section{前頭葉活動の非対称性と心拍の関係}

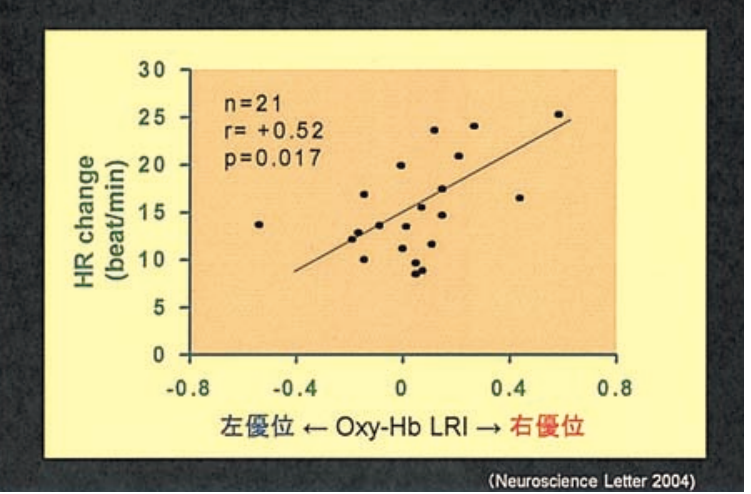

図14

体を介して間接的に脳を活性化する方法と言えるで しょう。

\section{中医学に対する脳科学研究 : ストレス反応と香療法 の効果}

私は，このような中医学の治療効果について，脳 科学のテクニックを用いて研究しております（資生 堂ライフサイエンス研究センター, 谷田正弘先生ら との共同研究)。具体的には, 先ほど申し上げた香 りで治療する香療法が，ストレスに対してどのよう なメカニズムで効果があるのか研究しているのです。 少し話しが戻りますが，中医学では，環境と人間と の相互作用がストレスの発生，あるいは逆にストレ スの治療に重要な役割を果たすと考えており，人間 を環境から分離された存在として見る西洋医学と比 較しますと，香療法などさまざまなストレスに対す る治療法があるわけです。これらの治療メカニズム を研究することは，中医学のエビデンスを得るとい う点で大変重要であると私は考えております。

さて，実験方法ですが，光トポグラフィーという 光脳機能イメージング法で暗算をさせた時の前頭葉 の活動を計測しました。暗算をさせましたのは，こ れがメンタルストレス課題としてストレスの研究に よく使用されるからです。そして同時に身体の反応， 特に心拍などの自律神経系機能，そして皮膚の状態， これは煩の皮脂とアクネ菌の量を測定しました。心 拍は暗算課題中の変化を見ておりますが，皮膚の状 態は暗算課題を与える前に測定しています。まず, 暗算課題に対する前頭葉の活動パターンと身体反応 の関係を明らかにし，次に香療法がこれらに対して どういう効果があるのか調べました。

最初の実験で, 暗算をさせると前頭葉の活動に二 


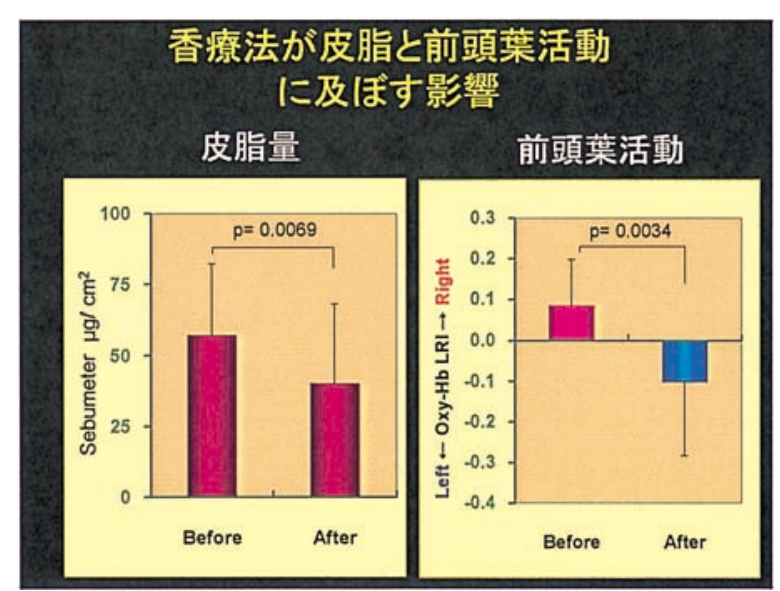

図16

つのパターンがあることが分かりました。つまり， 左の前頭葉の活動が右よりも大きい, 左優位タイプ と, もう一つは, 左よりも右が大きく活動する, 右 優位夕イプがあるのです (図13)。どの程度, 右優 位あるいは左優位があるか，それを判定するために， ラテラリティ・インデックス (laterality index), 偏 倚指数というものを算出しました。分母を右と左の 前頭葉の酸素化へモグロビンの濃度変化の和とし， 分子は右前頭葉の酸素化へモグロビンから左前頭葉 の酸素化へモグロビンを引いた差とします。こうす ると，右と左が同じ大きさであればゼロで，右優位 であればプラス，左優位であればマイナスになりま す。

心拍変化を見ますと, 暗算課題中に上昇し易い人 と, あまり変化のしない人がいることが分かりまし た。そこで心拍変化とラテラリティ・インデックス の関係を見ますと，両者の間に非常にきれいな正の 相関関係が出てきました (図14)。つまり，暗算課 題時に右の前頭葉が優位に活動する人ほど心拍の上 昇程度が高く，逆に左の前頭葉が優位な人はあまり 心拍が上昇しないということです。次に，ラテラリ ティ・インデックスと㚘頁の皮脂やアクネ菌との関係 を見ますと, やはり正の相関関係が得られ，右優位 に反応する人は皮膚の脂が多い脂性であり, さらに アクネ菌も多いということが分かりました（図15）。 これらをまとめますと, メンタルストレスに対して 右の前頭葉が優位に活動する人は, 脂性でアクネ菌 が多くニキビができ易い皮膚をしており，また ちょっとしたことにも心臓がドキドキする，ストレ スに反応しやすい人と言うことができます。

以上の結果をもとに，ストレスに反応しやすい人

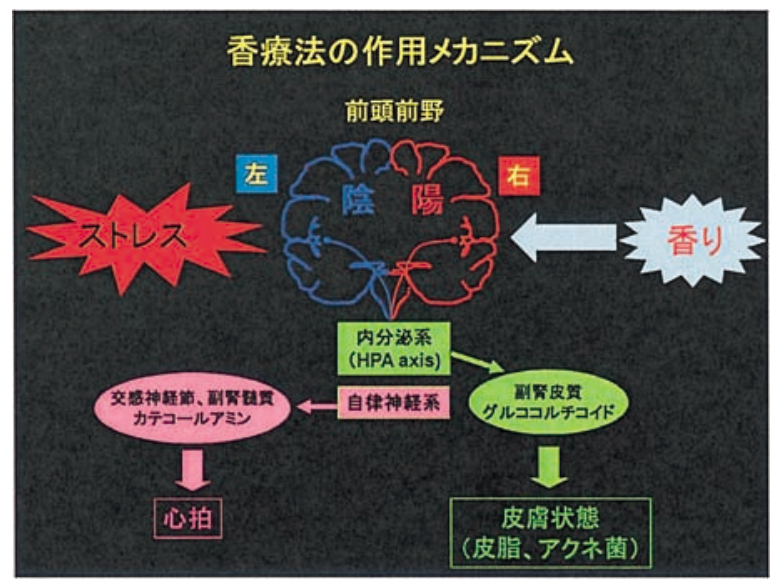

図17

を対象にして香療法の効果を調べました。今回は香 水を使用しましたが，調香師という香りをブレンド できる人が，それぞれの被験者が最も好きな匂いを ブレンドして作りました。この香水を 1 日 3 回使っ て，また，寝るときは枕元で瓶の蓋を開けて寝る。 そのようにして香水を使ってもらいながら 1 力月後 に同じストレス反応を計測しました。

これは香療法の効果を示したスライドです

16)。まず 1 力月後の皮脂ですが，香水を使用しな いコントロール群では前後の変化に有意差はありま せん。ところが, 香療法群では有意に皮脂の量が 減っていることが分かりました。さらに興味深いこ とに，暗算課題を与えた時の前頭葉の活動パターン が変わりました。コントロール群ではラテラリティ ・インデックスはプラスのままですが, 香療法群で はプラスからマイナスに変化しました。先ほど申し 上げましたように，プラスというのは右優位であり， それがマイナスになるということは左優位に変わっ たということです。つまり，ストレスに反応し易い 人に対して心地良い香りを 1 力月間かがせると，前 頭葉のストレスに対する活動パターンが変わり，か つ，皮膚の状態が良くなるということが分かったの です。

このスライドはストレス反応のメカニズムを示し ています (図17)。ストレスがかかりますと，間脳 一下垂体一副腎皮質系を介してグルココルチコイド などが分泌され，これが皮脂やアクネ菌を増やした りする。一方の脳幹部にある自律神経センターは, 交感神経, 副腎髄質カテコラミンを介して心拍を変 化させる。しかし, 実際にストレスというのは直接 間脳に行ったり，脳幹に行ったりするわけではなく， 
大脳がストレスセンサーとなっているわけですが, 最近までそのメカニズムはあまり分かっていません でした。今回の光学的計測法を用いた研究以外にも, 機能的 MRI を使った研究で, 前頭葉が自律神経系 や内分泌系を制御しているという研究結果が最近報 告されました。また, 解剖学的にも前頭葉から内分 泌系あるいは自律神経系のセンターにファイバーコ ネクションがあることも分かっています。このよう にストレスは，前頭葉を介していろいろな身体反応 を誘発することが次第に明らかになってきたのです。 さらに, 今回の研究結果は, 香療法の治療効果に前 頭葉が大きな役割を果たしていることを示唆してい ます。

中医学の五臓六腑には脳が含まれていませんが, 今回の研究結果を見ていますと, 脳, 特に前頭葉が 中医学に扔ける人体機能の中で重要な役割を果たし ているのではないかと考えられるわけです。さらに， ストレスに対する左右の前頭葉の活動バランスと身 体反応の関係から, 中医学における陰陽の源は, 左

（陰）と右（陽）の前頭葉にあるのではないかと想 像しております。

これは最後のスライドですが，パブロ・ピカソの
「泣く女」という有名な絵です。正面から見た部分 と側面から見た部分を組み合わせてダイナミックに 泣く女を表現している絵でありますが，正面から見 たところを西洋医学, 側面から見たところを東洋医 学と考えれば，私たちが目指す統合医療というもの は，ピカソの「泣く女」が一つのモデルになるので はないかと考えております。

以上で，私の話を終わらせていただきます。ご静 聴ありがとうございました。

佐藤 酒谷先生，大変ありがとうございました。 初めに陰陽五行説, それから中医学による脳と心, 中医学と脳科学についてご紹介をいただきました。 抄録を扯見していますと難しいなという感じでした が, ことに最後の香療法について, 近代医学的な素 晴らしい解析結果で, 中医学による医療もまさにエ ビデンスに基づくものであるということを，実際に 証明されたわけで，大変感動を覚えたご講演でした。 会員を代表して，心より御礼申し上げたいと思いま す。ぜひ今後もこういう研究方法を続けていただい て, 再び東洋医学会でご講演いただく機会があるこ とを祈念いたしたいと思います。 